\title{
INTRAMUSCULAR ADMINISTRATION OF STEROIDS IN TREATMENT OF RHEUMATOID ARTHRITIS
}

\author{
BY \\ JACK ZUCKNER, JAMAL UDDIN, AND ROBERT H. RAMSEY \\ Section on Arthritis, Department of Internal Medicine, St. Louis University School of Medicine, \\ St. Louis, Missouri
}

In a preliminary report (Zuckner, 1961) on intramuscular steroid therapy in patients with rheumatoid arthritis, results of approximately 100 injections of triamcinolone acetonide (hereafter referred to as TACTN)* and triamcinolone diacetate (or TDAC) $\dagger$ were described. The responses to this method of steroid administration were satisfactory in most cases, and compared favourably with those following the oral administration of steroids. In about 25 per cent. of cases, the anti-rheumatic effect was superior.

This study has been continued, and in the ensuing 18 months another 820 injections have been evaluated. Other steroids were also tried for comparison of their antirheumatic effectiveness by intramuscular administration. These included the depot preparation of 6-methyl prednisolone (referred to as $\mathrm{DM})_{+}^{+}$, triamcinolone acetonide tertiary-butylacetate (TATBA) $\uparrow$, and triamcinolone acetonide monoenanthate (TM)§. The chemical formulae of these preparations are shown in the figure opposite.

\section{Procedure}

TACTN, TDAC, DM, TATBA, and TM were injected intramuscularly into 86 patients with rheumatoid arthritis. These patients were classified (Table I) according to criteria of Steinbrocker, Traeger, and Batterman (1949), the majority being in Stage II, Class II. Their ages ranged from 32 to 75 years, most being in their fifties. There were 66 females and twenty males. The duration of disease was less than 5 years in about 40 per cent. and more than 10 years in one-third of the cases. Disease activity was graded 1 to 4 plus, and approximately 90 per cent. of the patients were considered to have 2 or 3 plus changes at the onset of the study.

* TACTN-Supplied by E. R. Squibb \& Sons, New Brunswick, New Jersey, and by Lederle Laboratories Division, American Cyanamid Company, Pearl River, New York.

+ TDAC, TATBA, and FAC-Supplied by Lederle Laboratories Division, American Cyanamid Company, Pearl River, New York.

$\ddagger$ DM-Supplied by The Upjohn Company, Kalamazoo, Michigan.

§ TM-Supplied by E. R. Squibb \& Sons, New Brunswick, New Jersey.
TABLE I

CLASSIFICATION OF PATIENTS WITH RHEUMATOID ARTHRITIS TREATED WITH INTRAMUSCULAR STEROIDS

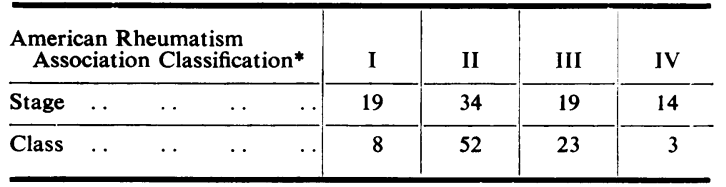

* Steinbrocker, Traeger, and Batterman (1949).

There were 900 injections of $100 \mathrm{mg}$. each. The amount of steroid injected was varied in a few individuals in an attempt to determine an optimum dose. Ten patients received a total of eleven injections of $50 \mathrm{mg}$. TACTN and these were compared with doses of $100 \mathrm{mg}$. TACTN in the same individuals. Nine injections of $140 \mathrm{mg}$. TACTN were compared with a $100 \cdot \mathrm{mg}$. dose in six cases. One hundred or more injections each of TACTN, TDAC, and DM were administered to 53, 47, and 68 patients, respectively (Table II, opposite).

Most injections (532) were of DM. A few injections of hydrocortisone acetate (FAC $\dagger$ ) in $500-\mathrm{mg}$. doses were also included for comparison; 22 patients received twenty or more injections; the greatest number for one patient was 38.

The different steroids were compared in individual cases only if at least two injections of each hormone were administered. In this manner, two, three, four, or, occasionally, all five steroids were evaluated in the same individual.

Thus, it was possible to compare TACTN, for example, with TDAC in 23 cases, with DM in 22 , with TM in seven, and with TATBA in ten cases. TDAC and DM were compared with the other steroids almost as frequently as described for TACTN. TM and TATBA were similarly evaluated about half as often.

During the study, not all the steroids mentioned were available at the same time. Therefore, it was not possible to rotate all the preparations at subsequent injection times in the same individual; however, the same steroid was usually not administered twice in succession. This random variation was done deliberately in an effort to minimize interfering factors which could appear from 
<smiles>CC(=O)OCC(=O)C1(C)C2CCC1C1CCC3=CC(=O)C=CC3(C)C1(C)C(O)C2</smiles>

triamcinolone Diacetate

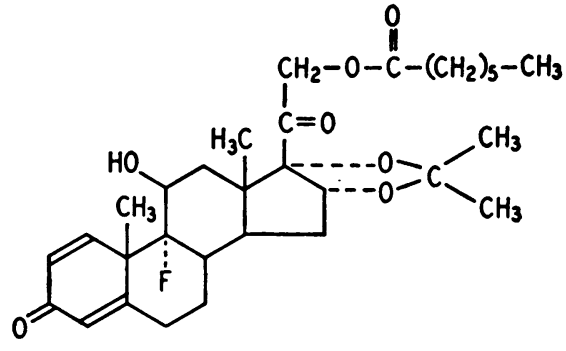

triaucinolone Acetonide Monoemanthate<smiles>CC1(C)OOC2(C(=O)CO)CC3C4CCC5=CC(=O)C=CC5(C)C4(C)C3(C)CC(O)C12C</smiles>

Triamcinolone acetonioe

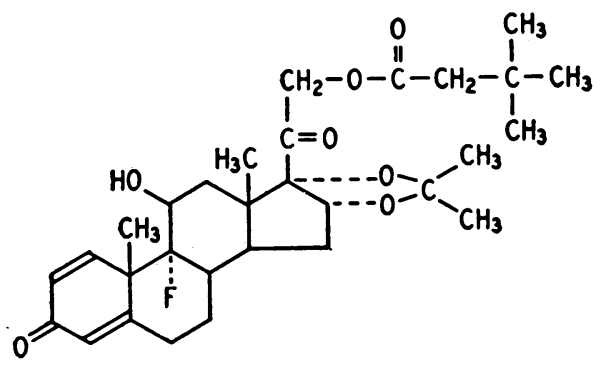

Triaucinolone Ace tomide Tertiary Butrlacetate<smiles>CC(=O)OCC(=O)C1(O)CCC2C3C[C@H](C)C4=CC(=O)C=CC4(C)C3C(O)CC21C</smiles>

Methylpredonsolone Acetate

Chemical composition of five steroid preparations.

TABLE II

NUMBER OF INTRAMUSCULAR INJECTIONS

\begin{tabular}{llll|c|c|c|c|c|c}
\hline Steroid &. & $\ldots$ &.. & $\begin{array}{c}\text { Triamcinolone } \\
\text { Acetonide }\end{array}$ & $\begin{array}{c}\text { Triamcinolone } \\
\text { Diacetate }\end{array}$ & $\begin{array}{c}\text { Depot Prepara- } \\
\text { tion of 6-Methyl } \\
\text { Prednisolone }\end{array}$ & $\begin{array}{c}\text { Hydrocortisone } \\
\text { Acetate }\end{array}$ & $\begin{array}{c}\text { Triamcinolone } \\
\text { Acetonide } \\
\text { Monoenanthate }\end{array}$ & $\begin{array}{c}\text { Triamcinolone } \\
\text { Acetonide } \\
\text { Tertiary- } \\
\text { Butylacetate }\end{array}$ \\
\hline Dose (mg.) &.. &. &.. & 100 & 100 & 100 & 500 & 100 & 100 \\
\hline No. of Patients &.. &.. & 53 & 47 & 68 & 11 & 18 & 28 \\
\hline Injections &.. &. &.. & 182 & 100 & 532 & 11 & 33 & 53 \\
\hline
\end{tabular}


one injection time to the next and which might possibly affect the results, such as, a spontaneous remission or an exacerbation of symptoms due to the inherent nature of the disease. There were, however, eighteen patients who received DM as the only injectable steroid over a period of time averaging 18 months for each. Three hundred and seventy-four injections of DM were administered to this group, averaging about 21 injections per patient.

Patients were usually examined once weekly at first, but with more prolonged observation, the interval between visits was lengthened to 2 to 4 weeks. The joints were evaluated at each visit for subjective improvement in pain, stiffness, and changes in mobility, and for objective improvement in tenderness, heat, swelling, range of motion, capsular thickening, and amount of synovial fluid present. A composite estimate of these findings was recorded as a percentage.

The interval between injections was usually determined by the patient's subjective response, particularly the return of significant pain. A degree of improvement greater than 50 per cent. was the intent in each subject, and a worsening to this level or lower after initial improvement was the indication for another injection. Although an effort was made to maintain improvement at a satisfactory level ( 50 per cent. or better), some of the patients dropped below this figure for a few days before their next injection of steroid.

The duration of observation varied (Table III). Approximately half the patients were studied for 1 year or more, and seven of these for more than 2 years.

Other therapy was continued as prescribed before the study was instituted with the exception of orally-adminis-

TABLE III

DURATION OF STUDY

\begin{tabular}{c|c}
\hline Length of Observation & Number of Patients \\
\hline (days) & \\
$1-100$ & 16 \\
$101-200$ & 15 \\
$201-365$ & 15 \\
$366-730$ & 33 \\
More than 2 yrs & 7 \\
\hline
\end{tabular}

tered steroids; 38 patients were receiving steroids orally at the onset, and in most instances, an attempt was made to discontinuc or lower their dose. In a few cases, when the beneficial effect from an injection of the intramuscularly administered hormone was diminishing and there was a wait of several days until the next visit, small doses of steroids were given orally to minimize worsening and to keep the patient more comfortable; 62 patients were receiving gold salt therapy, and almost all were taking salicylates simultaneously. In the group of eighteen patients who received DM as the only injectable steroid, only two were taking steroids orally at the time.

Signs of physiological side-effects and toxicity were sought at each visit. Observations were made for blood pressure changes, moon facies, ecchymoses, hirsutism, oedema, alterations in body weight, gastrointestinal disturbances, and other possible reactions. Laboratory procedures included blood counts, erythrocyte sedimentation rates (Westergren), and urine analyses. These were performed on the day of injection, at one week after each new steroid administration, and also at varying intervals during the study.

\section{Results}

The average duration of satisfactory improvement after a single injection of the $100 \mathrm{mg}$. TACTN, TDAC, DM, TM, and TATBA was approximately $20,16,18,16$, and 18 days respectively (Table IV). $500 \mathrm{mg}$. FAC resulted in improvement averaging $5 \cdot 2$ days per injection. Approximately $70-85$ per cent. of injections with any compound except FAC gave a satisfactory response. A satisfactory response was defined as greater than 50 per cent. improvement for 7 or more days. TACTN proved the most beneficial; 87 per cent. of injections were followed by a desirable outcome, averaging 20.5 days per injection. Table IV also records the longest periods of improvement from these steroids, extending to 6 months in one instance. Spontaneous remissions have to be considered here.

TABLE IV

RESULTS OF INTRAMUSCULAR STEROIDS IN RHEUMATOID ARTHRITIS

\begin{tabular}{|c|c|c|c|c|c|c|c|}
\hline Steroid & $\cdots$ & $\begin{array}{l}\text { Triamcinolone } \\
\text { Acetonide }\end{array}$ & $\begin{array}{c}\text { Triamcinolone } \\
\text { Diacetate }\end{array}$ & $\begin{array}{l}\text { Depot Prepara- } \\
\text { tion of 6-Methyl } \\
\text { Prednisolone }\end{array}$ & $\begin{array}{c}\text { Hydrocortisone } \\
\text { Acetate }\end{array}$ & $\begin{array}{c}\text { Triamcinolone } \\
\text { Acetonide } \\
\text { Monoenanthate }\end{array}$ & $\begin{array}{c}\text { Triamcinolone } \\
\text { Acetonide } \\
\text { Tertiary- } \\
\text { Butylacetate }\end{array}$ \\
\hline Dose (mg.) & $\ldots$ & 100 & 100 & 100 & 500 & 100 & 100 \\
\hline $\begin{array}{l}\text { Average Duration of } \\
\text { Improvement (days) }\end{array}$ & $\ldots$ & $20 \cdot 5$ & $15 \cdot 9$ & $18 \cdot 4$ & $5 \cdot 2$ & $16 \cdot 0$ & $17 \cdot 9$ \\
\hline Satisfactory* . & $\cdots$ & $87 \%$ & $75 \%$ & $80 \%$ & $36 \%$ & $70 \%$ & $67 \%$ \\
\hline $\begin{array}{l}\text { Longest Duration of } \\
\text { Improvement (days) }\end{array}$ & .. & 181 & 75 & 152 & 17 & $>49$ & 160 \\
\hline
\end{tabular}

- Greater than 50 per cent. improvement for 7 or more days. 
When $50 \mathrm{mg}$. TACTN was compared to $100 \mathrm{mg}$. TACTN in the same individuals, the larger injection proved to be more satisfactory for degree of improvement in seven of ten cases and for duration of beneficial effect in eight of ten cases, averaging about 8 days longer per injection. $140 \mathrm{mg}$. TACTN compared with $100 \mathrm{mg}$. TACTN in six cases resulted in a greater duration of improvement in five patients, averaging about 11 days longer per injection. The degree of improvement was approximately the same with the 100 and $140 \mathrm{mg}$. doses, except that two patients felt slightly better after the larger dose.

When at least two injections each of the different steroids were compared in individual patients, TACTN gave the most satisfactory results, being superior to TDAC in 15 of 23 , to DM in 13 of 22 , to TM in five of seven, and to TATBA in eight of ten patients. However, the results were not consistent, and TDAC proved superior to TACTN in eight patients, DM better than TACTN in nine patients, and TM and TATBA better than TACTN in two patients each.

At times there was a variability in response between one injection and the next. Thus, it was possible for a specific steroid to give satisfactory improvement after one injection, which was followed by a poor response after the next injection. This occurred with all the steroids studied, and its cause was not apparent. In many instances, there was no marked deterioration to indicate that any change had occurred which could have reduced the effectiveness of steroid therapy. However, a third dose of the same hormone often had a beneficial result once again.

The onset of improvement after an intramuscular steroid injection was usually first noted on awakening the next morning. A few patients experienced relief in as little as 3 to 5 hours after an injection, and some not until 48 hours afterwards. The improvement was most often at its maximum on the day after injection, but in a few individuals it gradually reached its maximum after several days.

Simultaneous treatment with salicylates and gold salts had no significant effect on the results. It was possible to discontinue the oral use of steroids in 27 of 38 patients who had been receiving oral steroids at the start of the study. It was usually easier to reduce the oral dose gradually, particularly if one were waiting for the total dosage of gold salts to accumulate to a therapeutic level in the body tissues. If doses of oral steroids were less than the equivalent of $12.5 \mathrm{mg}$. of prednisolone daily, abrupt discontinuation at the time of the first intramuscular injection was frequently possible.

In approximately 25 per cent. of patients, intra- muscular steroid therapy proved more satisfactory than oral. Only a few individuals expressed preference for the oral route. In ten patients a combination of intramuscular and oral steroids proved more beneficial than either alone.

\section{Side-Effects}

The significant side-effects are shown in Table V.

TABLE V

SIDE-EFFECTS OF INTRAMUSCULAR STEROIDS, 86 PATIENTS

\begin{tabular}{|c|c|c|c|c|c|}
\hline \multicolumn{4}{|c|}{ Side-Effect } & $\begin{array}{l}\text { Number } \\
\text { of } \\
\text { Patients }\end{array}$ & $\begin{array}{c}\text { Number of Patients } \\
\text { also on } \\
\text { Oral Steroids }\end{array}$ \\
\hline $\begin{array}{l}\text { Moon facies ... } \\
\text { Ecchymoses ... } \\
\text { Hirsutism } \ldots \\
\text { Diuresis ... } \\
\text { Muscle cramps } \\
\text { Flushing } \ldots \\
\text { Epigastric burning } \\
\text { Nausea and/or vom } \\
\text { Anorexia .. } \\
\text { Duodenal ulcer } \\
\text { Tiredness and weak } \\
\text { Euphoria . . } \\
\text { Severe pain at site } \\
\text { Nervousness . . } \\
\text { Headache . } \\
\text { Increased appetite } \\
\text { Soft tissue atrophy a } \\
\text { Dizziness } \\
\text { Raised blood pressu } \\
\text { Glycosuria . } \\
\text { Acne .. } \\
\text { Menstrual changes } \\
\text { Posterior subcapsul } \\
\text { Abdomen "hot" ar } \\
\text { shortly after injec }\end{array}$ & $\begin{array}{l}\ldots \\
\ldots \\
\ldots \\
\ldots \\
\ldots \\
\text { iiting } \\
\ldots \\
\ldots \\
\text { ness } \\
\text { of inje } \\
\ldots \\
\ldots \\
\therefore \\
\text { site o } \\
\text { are } \\
\ldots \\
\cdots \\
\text { ar cata } \\
\text { ad eup } \\
\text { ction }\end{array}$ & $\begin{array}{l}\ldots \\
\ldots \\
\ldots \\
\ldots \\
\ldots \\
\ldots \\
\ldots \\
\ldots \\
\text { ection } \\
\ldots \\
\ldots \\
\therefore \\
\ldots \\
\ldots \\
\ldots \\
\ldots \\
\text { inject } \\
\text { racts } \\
\ldots\end{array}$ & 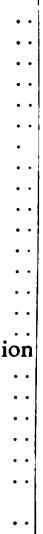 & $\begin{array}{r}30 \\
31 \\
13 \\
11 \\
8 \\
7 \\
5 \\
4 \\
1 \\
1 \\
5 \\
1 \\
3 \\
2 \\
2 \\
3 \\
1 \\
3 \\
1 \\
2 \\
2 \\
4 \\
3 \\
1\end{array}$ & $\begin{array}{l}7 \\
5 \\
= \\
\frac{1}{1} \\
= \\
= \\
= \\
= \\
= \\
= \\
=\end{array}$ \\
\hline
\end{tabular}

It was not possible to indict a specific steroid as the cause of any particular physiological change or toxic reaction because the steroids were given in rotation and the cumulative effect had to be considered. The recorded side-effects include data from the eighteen patients treated with DM alone as these findings were similar to the rest. Some patients were taking oral and intramuscular steroids simultaneously, so that one could not distinguish the reactions due to the latter alone. Thus, although moon facies, ecchymoses, and hirsutism were the most common physiological side-effects, about 30 per cent. of the patients so affected were receiving oral as well as intramuscular steroids.

Moon Facies.-This definitely diminished after several months of intramuscular therapy in five patients who received injections at intervals of at least 3 weeks. A like number of cases showed an increase in moon facies and hirsutism, but they received the steroid injections more frequently. 
Ecchymoses.-These were very common and tended to recur for many months after the last injection.

Diuresis.-Eleven patients noted this after the injections.

Oedema.-If ankle oedema was present, it would, in many instances, disappear after an injection, only to recur when the beneficial effect from the medication had waned.

Muscle Cramps.-These were also not infrequent, but were generally adequately controlled by quinine or Benadryl* prescribed at bedtime.

Gastrointestinal Complaints.-These were very few and much less than those caused by oral steroids in the same patients. Epigastric burning, nausea, vomiting, and anorexia were noted infrequently. Only one patient developed a duodenal ulcer during treatment with intramuscular steroids, but he had a previous history of peptic disease. Three individuals had an increase in appetite. Routine $x$ rays of the gastrointestinal tract were not taken.

Extreme Tiredness and Weakness.-Occasionally associated with nausea and vomiting, this occurred in five patients about 10 to 14 days after the steroid injections. These symptoms corresponded with worsening of joint complaints and were suggestive of adrenal insufficiency or of the withdrawal syndrome noted after abrupt discontinuation of oral steroid therapy. Electrolyte determinations for sodium, chloride, and potassium in two of these patients at the time of symptomatology did not, however, reveal any abnormalities. These symptoms were relieved by a subsequent steroid injection; or, if none were given, would persist for 2-4 days and then usually disappear.

Atrophy of Soft Tissues.-This developed in one patient over the deltoid injection site in an area measuring approximately $4 \times 4 \times 2 \mathrm{~cm}$. This persisted for 6 months, but then gradually filled in completely. There had been twelve intramuscular injections of the different steroids in this region. No abscesses occurred.

Transient Glycosuria.-This appeared in two patients, who had had injections on an average of every 4 weeks; the glycosuria was not present at each visit. No antidiabetic therapy was necessary.

Posterior Subcapsular Cataracts.-These were discovered in three patients who had visual complaints; they had all been on long-term oral steroid therapy before the intramuscular injections were given. Under investigation at present is a study to evaluate the incidence of this complication in our patients.

Osteoporosis.-No patient complained of symptoms suggestive of osteoporosis, but routine $x$ rays of bone were not obtained to determine the relative frequency of this disturbing physiological effect.

Not all injections of the same hormone resulted in similar reactions in the same individual. For example, euphoria, muscle cramps, weakness, and

\footnotetext{
* Diphenhydramine hydrochloride.
}

gastrointestinal complaints did not occur consistently after similar steroid injections.

\section{Discussion}

Despite favourable responses to steroid therapy in many illnesses, undesirable side-effects accompanying prolonged administration are still of major concern. In an effort to eliminate or temper these complications, newer preparations have been developed, and methods of administration other than the usual oral procedure have been tried. Unfortunately, all the anti-inflammatory hormones so far made available still cause many of the same harmful reactions. Different methods of administration have been attempted with partial success, as with the intra-articular injection of steroids and its wellestablished advantages. However, this latter method is limited because it results in local improvement only and does not satisfy the needs of those with more extensive disease. Recently, Harter, Reddy, and Thorn (1963) described an intermittent oral corticosteroid dosage regimen with encouraging results. Their subjects had substantially reduced side-effects, in particular less adrenal suppression.

That the intramuscular method is effective is demonstrated by the satisfactory responses which followed the great majority of injections in this study. TACTN proved to be most desirable. Eightyseven per cent. of injections with this steroid gave a beneficial effect which persisted for an average of approximately 20.5 days per administration. Other reports (West, 1962; Norcross and Winter, 1961; Hartfall, Walker, and Wright, 1962; Schwartz, 1963) in the literature confirm this impression of the efficacy of intramuscular steroid therapy. West (1962) treated sixteen patients with weekly intramuscular injections of prednisolone acetate for $3 \frac{1}{2}$ years with favourable responses, the antiinflammatory effect being about the same as with oral steroids. Norcross and Winter (1961) injected DM intramuscularly; they felt that it offered certain advantages over oral steroids in selected patients, but did not recommend it for routine administration. Hartfall and others (1962) gave prednisolone trimethylacetate intramuscularly to seventeen patients and reported improvement in nine. Schwartz (1963) found intramuscular steroids valuable for long-term treatment, his patients being improved for 14 to 21 days after one injection of $40 \mathrm{mg}$. TACTN. In our study, about 25 per cent. of patients responded better to intramuscular than to oral steroids, and about 10 per cent. seemed to be better when oral and intramuscular steroids were used simultaneously. 
Side-effects. -The known side-effects of oral steroids were also observed with intramuscular therapy, the frequency and severity of the reactions depending to a great extent on the interval between injections. If 4 weeks or more elapsed between injections, such side-effects as moon facies, hirsutism, and acne, for example, were less frequent and less intense. Since it was possible to obtain satisfactory therapeutic responses in many patients with such widely-spaced injections, this method proved more desirable for them. Injections given more often than once every 3 weeks were followed by complications similar to or more severe than those due to oral steroids. Consequently, the interval between injections should be as long as possible; they should be repeated only when considered essential because of significant worsening in the patient's condition, and not given routinely at set intervals.

The dose per injection is also very important when considering side-effects, but as $100 \mathrm{mg}$. was used for the majority of injections in this study, a proper evaluation of the relationship of dose to toxicity was not possible.

The various authors who have used the intramuscular route have all concluded that gastrointestinal complications are definitely fewer than with oral steroids, and this has also been our experience.

Other Advantages.-Besides the advantages already mentioned (i.e. greater anti-inflammatory effect in certain patients and less toxicity if the injections are widely separated), other considerations are pertinent:

(1) The medication is expensive, but the total cost may be less than that of oral therapy if the injections are not too frequent.

(2) Withdrawal symptoms seem to be less marked and can be controlled if they do occur with small oral doses.

(3) The intramuscular method of administration is relatively simple, and the regulation of dosage by gradual reduction or addition can be avoided in most instances.

Dosage.-To determine the optimum dose, injections of 50 and $140 \mathrm{mg}$. TACTN were given to some patients and compared with the $100 \mathrm{mg}$. dose. The $50 \mathrm{mg}$. dose was significantly less satisfactory, and the improved response to the $140 \mathrm{mg}$. dose did not seem to warrant its routine use because of the risk of greater toxicity. Doses between 50 and $100 \mathrm{mg}$. were not evaluated, but the $100 \mathrm{mg}$. dose proved very efficacious for most patients in this study.
Prolonged Response.-The reason for the prolonged response which followed the intramuscular injections of TACTN, TDAC, DM, TM, and TATBA is not known. A "depot" effect may partly explain it, and to test this, five of our patients were given DM intramuscularly and tablets of 6-methyl prednisolone orally in the same $100 \mathrm{mg}$. dose, but at different times. Oral therapy gave 2 days' improvement, whereas the intramuscular route gave 3 weeks. This type of information supports the likelihood of a "depot" effect. However, certain unknown factors (such as, the rate of absorption through the gastrointestinal tract of the orally administered steroid, the amount absorbed, and the importance of passage through the portal circulation as the initial pathway for the steroid) require evaluation. The development of better methods of assaying the blood levels of these steroids should give definite answers. The prolonged response may be due to an initial high blood level of the drug resulting from the large dose injected. Higher concentrations of steroid may thus enter the inflamed synovial cells and suppress the inflammation more efficiently, particularly if the permeability of these cells is altered by inflammation. Passage through the systemic circulation before the portal circulation, thus temporarily avoiding the effect of the liver cells on the metabolism of the steroids, may also leave more steroids available to enter the inflamed synovial cell. However, since the steroid levels may be assumed to have been high in the blood of the patients who received $100 \mathrm{mg}$. 6-methyl prednisolone orally, but responded poorly, the significance of this explanation is doubtful.

Summary
The intramuscular administration of steroids in an attempt to combine a good anti-inflammatory response with relatively minor toxicity was tested in a series of 920 injections. The desired anti-inflammatory effect was obtained in approximately 70-85 per cent. of instances with $100 \mathrm{mg}$. injections of TACTN, TDAC, DM, TM, and TATBA, most frequently with TACTN. The duration of improvement was greatest following the administration of TACTN (average 20.5 days per injection). A 50-mg. dose of TACTN was significantly less satisfactory than the $100 \mathrm{mg}$. dose. The greater improvement in a few patients after a 140-mg. dose of TACTN did not seem to warrant the use of this large dose routinely because of the greater risk of toxicity.

Evaluation of toxic side-effects will require more prolonged observation, but there is evidence that if injections are relatively widely spaced (i.e. more than 3 weeks apart), the side-effects may be fewer than 
with oral steroids. Intramuscular treatment may be particularly advantageous in limiting gastrointestinal complications. About 25 per cent. of the patients derived more satisfactory relief from intramuscular steroid therapy than from previous oral steroid therapy.

\section{REFERENCES}

Harter, J. G., Reddy, W. J., and Thorn, G. W. (1963). New Engl. J. Med., 269, 591.

Hartfall, S. J., Walker, W. C., and Wright, V. (1962). Acta rheum. scand., 8, 258.

Norcross, B. M., and Winter, J. A. (1961). N.Y. St. J. Med., 61, 552.

Schwartz, S. (1963). Curr. ther. Res., 5, 431.

Steinbrocker, O., Traeger, C. H., and Batterman, R. C. (1949). J. Amer. med. Ass., 140, 659.

West, H. F. (1962). Ann. rheum. Dis., 21, 191.

Zuckner, J. (1961). Ibid., 20, 274.

\section{Administration intramusculaire de stéroïdes dans le traitement de l'arthrite rhumatismale}

\section{RÉSUMÉ}

On a étudié l'administration intramusculaire de stéroïdes par une série de 920 injections pour trouver une bonne réponse anti-inflammatoire avec un minimum rélatif de toxicité. L'effet anti-inflammatoire désiré fut obtenu en 75-85 pour cent des cas avec $100 \mathrm{mg}$. de 6-methyl prednisolone dépôt et avec chacune des quatre préparations de triamcinolone: acétonide, diacétate, acétonide monoenanthate et acétonide butylacétate terciaire, mais le plus souvent avec l'acétonide de triamcinolone (TACTN). La durée de l'amélioration fut la plus longue après l'administration de TACTN $(20,5$ jours par injection en moyenne). Une dose de $50 \mathrm{mg}$. de TACTN fut significativement moins satisfaisante que la dose de $100 \mathrm{mg}$. Le fait que l'amélioration fut plus prononcée chez quelques malades avec une dose de 140 mg. de TACTN ne justifie pas son emploi régulier en raison du risque plus grand de toxicité.

L'évaluation des effets toxiques exige une observation plus longue, mais on sait déjà que lorsque l'intervalle entre les injections est assez long (c.-à-d. plus de trois semaines) les effets secondaires sont moins fréquents qu'avec les stéroïdes par voie orale. Le traitement intramusculaire est particulièrement avantageux pour limiter les complications gastro-intestinales. Près de 25 pour cent des malades dérivaient un soulagement plus satisfaisant de la thérapie stéroïde intramusculaire que de la thérapie stéroïde antérieure par la voie orale.

\section{Administración intramuscular de esteroides en el tratamiento de la artritis reumatoide}

\section{Sumario}

Se estudió la administración intramuscular de esteroides en una serie de 920 inyecciones para hallar una buena respuesta anti-inflamatoria con un mínimo relativo de toxicidad. El efecto anti-inflamatorio deseado fué obtenido en un 75-85 por ciento de los casos con $100 \mathrm{mg}$. de 6-metil prednisolona depôt y con cada de las cuatro preparaciones de triamcinolona: acetonido, diacetato, acetonido monoenantato y acetonido butilacetato terciario, pero con la mayor frecuencia con el acetonido de triamcinolona (TACTN). La duración de la mejoría fué mayor después de la administración de TACTN (20,5 días en promedio por inyección). Una dosis de $50 \mathrm{mg}$. de TACTN fué significativamente menos satisfactoria que la dosis de $100 \mathrm{mg}$. La mejoría más pronunciada en algunos enfermos con una dosis de 140 mg. de TACTN no justifica su empleo regular en vista del riezgo de mayor toxicidad.

La valoración de los efectos tóxicos necesitaría más larga observación, pero existen datos mostrando que con un intervalo entre las inyecciones suficiente (p.ej.más de tres semanas) los efectos secundarios son menos frecuentes que con esteroides por vía oral. El tratamiento intramuscular es particularmente ventajoso para limitar las complicaciones gastrointestinales. Cerca de un 25 por ciento de los enfermos experimentaron un alivio más satisfactorio con la terapia esteroide intramuscular que con la terapia esteroide previa por vía oral. 